\title{
Sociodemographic determinants of diet quality of the EU elderly: a comparative analysis in four countries
}

\author{
Xavier Irz ${ }^{1, *}$, Laura Fratiglioni ${ }^{2}$, Nataliya Kuosmanen ${ }^{1}$, Mario Mazzocchi $^{3}$, \\ Lucia Modugno ${ }^{3}$, Giuseppe Nocella ${ }^{4}$, Behnaz Shakersain ${ }^{2}$, W Bruce Traill ${ }^{4}$, Weili Xu ${ }^{2}$ \\ and Giacomo Zanello ${ }^{4}$ \\ ${ }^{1}$ Economic Research Unit, MTT Agrifood Research Finland, Latokartanonkaari 9, 00790 Helsinki, Finland: \\ ${ }^{2}$ Karolinska Institutet and Aging Research Center, Stockholm University, Stockholm, Sweden: ${ }^{3}$ Department of \\ Statistics, University of Bologna, Bologna, Italy: ${ }^{4}$ Department of Food Economics and Marketing, University of \\ Reading, Reading, UK
}

Submitted 12 September 2012: Final revision received 31 January 2013: Accepted 17 March 2013: First published online 9 May 2013

\begin{abstract}
Objective: To investigate the sociodemographic determinants of diet quality of the elderly in four EU countries.

Design: Cross-sectional study. For each country, a regression was performed of a multidimensional index of dietary quality $v$. sociodemographic variables.

Setting: In Finland, Finnish Household Budget Survey (1998 and 2006); in Sweden, SNAC-K (2001-2004); in the UK, Expenditure \& Food Survey (2006-07); in Italy, Multi-purpose Survey of Daily Life (2009).

Subjects: One- and two-person households of over-50s (Finland, $n$ 2994; UK, $n$ 4749); over-50s living alone or in two-person households (Italy, $n$ 7564); over-60s (Sweden, $n$ 2023).

Results: Diet quality among the EU elderly is both low on average and heterogeneous across individuals. The regression models explained a small but significant part of the observed heterogeneity in diet quality. Resource availability was associated with diet quality either negatively (Finland and UK) or in a non-linear or nonstatistically significant manner (Italy and Sweden), as was the preference for food parameter. Education, not living alone and female gender were characteristics positively associated with diet quality with consistency across the four countries, unlike socio-professional status, age and seasonality. Regional differences within countries persisted even after controlling for the other sociodemographic variables. Conclusions: Poor dietary choices among the EU elderly were not caused by insufficient resources and informational measures could be successful in promoting healthy eating for healthy ageing. On the other hand, food habits appeared largely set in the latter part of life, with age and retirement having little influence on the healthiness of dietary choices.
\end{abstract}

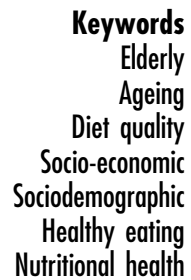

It is now well established that the EU population is ageing, which creates important challenges for the functioning of public services and raises fundamental questions about the evolution of human welfare. A few figures help appreciate the magnitude and speed of the changes ahead. Eurostat forecasts that the proportion of the EU population over the age of 65 years (80 years) will increase steadily from $16 \cdot 0 \%$ $(4 \cdot 1 \%)$ in 2010 to $27 \cdot 8 \%(10 \cdot 1 \%)$ in $2050^{(1)}$. Meanwhile, the demographic projections of the ANCIEN project of the EU Seventh Framework Programme suggest that life expectancy at age 65 years will increase by about 3 years from 2008 to $2040^{(2)} \uparrow$ The problems that this evolution

$\uparrow$ Even more starkly, the number of centenarians in the UK is projected to increase from 14500 in 2012 to 110000 in $2035^{(3)}$. entails for the funding of pensions, organisation of social care and funding of health services are well known, but there also concerns that longer lives can have grim consequences for the elderly themselves, with prolonged periods of disability, functional limitations, ailments and/or vegetative existence before death. As a result, healthy ageing, defined as the prevention of diseases as well as the delaying of the deterioration of health status, has become a key objective of European public health policy.

Although the question of whether people in the industrial world are living not only longer but also better remains open, $\$$ science has now clearly established that

\$ For instance, in the UK the Office of National Statistics has found that mostly fell for men at age 65 years between $2004-06$ and $2007-09^{(6)}$. the proportions of life spent disability-free increased for women but 
ageing processes are fortunately modifiable ${ }^{(4)}$. In particular, evidence is accumulating that nutrition interacts with the ageing process in numerous ways and it is therefore believed that healthy eating can be used to slow functional declines and the onset of age-related chronic diseases ${ }^{(5)}$. However, in addition to robust scientific assessment of the nutrition-ageing relationship, effective nutritional policy for healthy ageing requires a clear understanding of what is driving the elderly to adopt particular diets and what can be done at population or individual level to increase the healthiness of those diets.

Although these questions have been the subject of some research, a literature review indicates some important gaps in knowledge: only a small number of studies have investigated the EU elderly specifically and, while research so far has identified a large number of potential drivers of diet quality and food choices among the elderly, the influence of each factor is rarely quantified and identified ceteris paribus. This makes interpretation of the observed associations difficult because of possible confounding and, as a result, the fundamental barriers to the adoption of healthy diets remain unclear. For instance, an unconditional positive association between income and diet quality cannot establish whether poor diets are driven by a lack of resources or limited education, as the latter is strongly correlated with the former. While recognising the merits of unconditional analysis for targeting policies ${ }^{(7)}$, we believe that the conditional approach that we follow brings more insights for the design of policies to promote healthy eating (e.g. choice of income transfer $v$. informational campaign).

Against this background, the present paper analyses the economic, social and demographic determinants of diet quality among elderly individuals in four EU countries, namely the UK, Italy, Sweden and Finland.

\section{Materials and methods}

\section{Index of dietary quality}

Although many studies have investigated the determinants of diet quality by focusing on a single dietary component (e.g. saturated fat, fruit and vegetable intake), a more holistic approach considering the entire diet seems preferable in order to guide policy ${ }^{(8)}$. Multidimensional indices of diet quality have therefore been developed, with a large number of variants reflecting somewhat arbitrary choices regarding the foods and nutrients included and the aggregation procedure (e.g. cut-off values, scoring methods) as described in the detailed reviews of Kant ${ }^{(9)}$ and Waijers et al. ${ }^{(10)}$. The choice of index is difficult as none has been shown to be more strongly associated with health outcomes ${ }^{(10)}$, but four original indices (Healthy Eating Index, Diet Quality Index (DQI), Mediterranean Diet Score, Healthy Eating Indicator) have been validated and used most extensively. Ultimately, based on these reviews, data availability and the objective of ensuring consistency across the country data sets, the DQI of Patterson et al. ${ }^{(11)}$ was selected. As our investigation was part of the large EU-funded NU-AGE project on healthy ageing, this choice was also discussed and agreed within the project with experts in nutrition of the elderly. The following important modifications were then made to the original DQI.

1. For each of its components, the original DQI takes only integer values of 0,1 and 2 . This creates arbitrary discontinuities and we therefore preferred to build each component as a continuous piece-wise linear function between the minimum value, set at 0 , and the maximum value, set at 10 .

2. The original DQI was based on the US nutritional recommendations, which do not suit the European context. It was therefore adjusted in view of the Finnish Nutritional Recommendations.*

Table 1 describes the specific criteria used to define the bounds of the eight components of the DQI, which covers intakes of macronutrients (total fat, saturated fat, protein and carbohydrate), cholesterol, minerals (sodium and calcium) and fruits and vegetables. The score takes a value between 0 and 80 .

The Italian data set only provides a dietary record at a high level of product aggregation. This information is not detailed enough to allow calculation of some of the components of the DQI focusing on micronutrients (e.g. calcium). Hence, the alternative Recommendation Compliance Index (RCI) of Mazzocchi et al. ${ }^{(12)}$ was used to measure diet quality on the Italian data, as this index is based on relative dietary composition (e.g. shares of energy intake from various nutrients) and its distance from the recommended WHO diet. While this complicates the comparison of results across countries, a check on the UK data that allows computation of both indices indicated a significant and high degree of correlation between RCI and DQI scores. $\dagger$

\section{Data}

A data mapping exercise covering the four countries as well as the EU was carried out in order to identify secondary data sets suitable for the analysis. The key selection criteria included the number of observations specifically on older individuals, year of collection, comprehensiveness of the food and nutrient intake data, and extensiveness of the socio-economic information collected. On that basis, we selected the four data sets described succinctly in Table 2 . With one exception in the

\footnotetext{
* We did not adjust the definition of the DQI to reflect the recommendations in each of the four countries because this would have made comparison of the country-level results difficult. Given that our focus is on heterogeneity of diets, the choice of the benchmark recommendations has a negligible impact on the results.

$\uparrow$ The correlation coefficient was $0 \cdot 70$.
} 
Table 1 Diet quality indices

\begin{tabular}{lccc}
\hline \multicolumn{4}{c}{ Diet Quality Index (DQI) } \\
\hline Component & $\begin{array}{c}\text { Criterion for } \\
\text { score }\end{array}$ & $\begin{array}{c}\text { max score } \\
\text { of } 10\end{array}$ & $\begin{array}{c}\text { Criterion for } \\
\text { min score } \\
\text { of } 0\end{array}$ \\
\hline 1. Total fat & $0-10$ & $<30 \mathrm{E} \%$ & $>40 \mathrm{E} \%$ \\
2. Saturated fat & $0-10$ & $<10 \mathrm{E} \%$ & $>13.3 \mathrm{E} \%$ \\
3. Cholesterol & $0-10$ & $<300 \mathrm{mg} / \mathrm{d}$ & $>400 \mathrm{mg} / \mathrm{d}$ \\
4. Sodium & $0-10$ & $<2000 \mathrm{mg} / \mathrm{d}$ & $>2800 \mathrm{mg} / \mathrm{d}$ \\
5. Calcium & $0-10$ & $\geq 800 \mathrm{mg} / \mathrm{d}$ & $<533 \mathrm{mg} / \mathrm{d}$ \\
6. Fruits and vegetables & $0-10$ & $5 \mathrm{servings} / \mathrm{d}$ & $\leq 2 \mathrm{servings} / \mathrm{d}$ \\
7. Protein & $0-10$ & $\leq 100 \% \mathrm{DRI}$ & $>150 \% \mathrm{DRI}$ \\
8. Total carbohydrates & $0-10$ & $\geq 55 \mathrm{E} \%$ & $<37 \mathrm{E} \%$ \\
\multicolumn{4}{c}{ Recommendation Compliance Index (RCl, Italy) }
\end{tabular}

\begin{tabular}{lc}
\hline Component & $\begin{array}{c}\text { Criterion to meet recommendation } \\
(\text { score }=1)\end{array}$ \\
\hline 1. Fats & $15-30 \mathrm{E} \%$ \\
2. Saturated fat & $<10 \mathrm{E} \%$ \\
3. Trans-fats & $<1 \mathrm{E} \%$ \\
4. Carbohydrate & $55-75 \mathrm{E} \%$ \\
5. Protein & $10-15 \mathrm{E} \%$ \\
6. Fruits and vegetables & 5 servings $/ \mathrm{d}(\mathrm{or} 400 \mathrm{~g} / \mathrm{d})$ \\
7. Raw sugar & $\leq 10 \mathrm{E} \%$ \\
\hline
\end{tabular}

E\%, percentage of energy; DRI, Dietary Reference Intake.

case of Sweden, the data were not derived from surveys targeting the elderly specifically and it was therefore necessary to define a minimum age of eligible individuals. Although the traditional definition of the elderly sets an age limit of 65 years, we decided to lower that limit to 50 years to provide a basis for comparison of elderly and non-elderly households/individuals. Another reason for this age limit was that we also wanted to understand the potential impact of retirement on food choices and diet quality, which requires data on both retired and active individuals.* A broader age bracket also allowed us to better appreciate the impact of ageing on diet quality, while giving us larger samples. $\dagger$ For Finland and the UK, the data recorded information at the level of the household rather than the individual and, in those cases, only one- and two-person households formed of individuals over the age limit were selected. $\$$ In order to improve consistency, individual data taken from the Italian data set only included those aged above 50 years who lived alone or in two-person households. Finally, in order to limit the influence of outliers on the results, observations with

\footnotetext{
* We recognise that the term 'elderly' does not describe very well the demographic group over the age of 50 years, but we keep it for convenience and conciseness.

$\uparrow$ A more minor reason relates to the fact that the socio-professional status of individuals over the age of 65 years is often not described in detail, as they are usually lumped together into a 'pensioner' category.

$\$$ Hence, in the case of the UK, Italy and Finland, we ignored the elderly individuals living with non-elderly individuals. For Finland, the available data allowed us to calculate that a large majority of those aged 65 years and over in the sample belonged to the types of households selected in the analysis.
}

extreme values for the eight nutrient (or food) intakes entering the DQI were excluded by removing the $1 \%$ tail of the distribution on each side.

\section{Multivariate regression analysis}

Given the high level of correlation among sociodemographic variables (e.g. education and income), multivariate regression models were used to quantify the association of each variable to diet quality ceteris paribus. Further, a common model was defined for the four samples in order to maximise comparability of results and ease of interpretation. The exact selection of explanatory variables was guided by existing literature as well as availability of particular data in the four samples, resulting in the model defined in the left column of Table 3. Some important remarks are in order.

1. Although resource availability is often mentioned as a key driver of the food choices of the elderly, constructing a related variable for empirical analysis raises several difficulties. Income is not particularly appropriate to measure the resources available for consumption because pensioners often fund their expenses from savings. Meanwhile, the food budget is itself endogenous in the sense that it results from a choice, so that regression models including that variable may be spurious. Ultimately, resource availability was measured by total consumption expenditure where possible (UK and Finnish samples) with two adjustments. First, in multi-individual households, economies of scale in consumption were accounted for by dividing total household expenditure by the number of consumption units (rather than individuals) as defined by the Organisation for Economic Co-operation and Development.\$ Second, the expenditure variable entered the model in logarithmic terms to accommodate the broad range of the data.

2. The Italian and Swedish data sets measure financial resources only through answers to qualitative questions, which were included through appropriate dummy variables.

3. In the two data sets that measure expenses quantitatively, it was possible to build a preference for food variable defined as the share of total expenditure allocated to food.

4. The educational levels, referred to as primary, secondary and tertiary in the text, were defined in each country and introduced into the model through two dummy variables (the reference category in

\footnotetext{
$\S$ In practice, this means dividing total expenditure of two-person households by $1 \cdot 5$.

\|I In the Swedish data set, the resource constraint is measured by a yes/no answer to the question 'Do you face difficulties in taking care of your daily expenses?'; in the case of Italy, the respondents were simply asked to characterize their financial resources as being insufficient, poor, adequate or very good.
} 
Table 2 Characteristics of the four data sets

\begin{tabular}{|c|c|c|c|c|c|c|c|c|c|}
\hline \multirow[b]{2}{*}{ Country } & \multicolumn{4}{|c|}{ General characteristics } & \multicolumn{2}{|c|}{ Observations included } & \multicolumn{3}{|c|}{ Food data } \\
\hline & Name & Level and type & $\begin{array}{l}\text { Representa- } \\
\text { tiveness }\end{array}$ & Year(s) & Criteria & $n$ & Type & Collection & $\begin{array}{l}\text { Composition } \\
\text { database }\end{array}$ \\
\hline UK & $\begin{array}{l}\text { Expenditure and } \\
\text { Food Survey } \\
\text { (EFS) }\end{array}$ & $\begin{array}{l}\text { Household, } \\
\text { cross-sectional }\end{array}$ & $\begin{array}{l}\text { Nationally for } \\
\text { whole } \\
\text { population }\end{array}$ & 2006 and 2007 & $\begin{array}{l}\text { One- and } \\
\text { two-person } \\
\text { households, } \\
\text { age } \geq 50 \text { years }\end{array}$ & 4749 & $\begin{array}{l}\text { Quantity and } \\
\text { expenditure } \\
\text { information on } \\
\text { food and drinks } \\
\text { purchases, more } \\
\text { than } 500 \text { food } \\
\text { codes }\end{array}$ & $\begin{array}{l}\text { Two-week diary } \\
\text { (including food } \\
\text { eaten out) }\end{array}$ & $\begin{array}{l}\text { Department for } \\
\text { Environment, } \\
\text { Food and Rural } \\
\text { Affairs }\end{array}$ \\
\hline Finland & $\begin{array}{l}\text { Household Budget } \\
\text { Survey }\end{array}$ & $\begin{array}{l}\text { Household, } \\
\text { cross-sectional }\end{array}$ & $\begin{array}{l}\text { Nationally for } \\
\text { whole } \\
\text { population }\end{array}$ & 1998 and 2006 & $\begin{array}{l}\text { One- and } \\
\text { two-person } \\
\text { households, } \\
\text { age } \geq 50 \text { years }\end{array}$ & 2994 & $\begin{array}{l}\text { Consumption, } 254 \\
\text { COCIP codes }\end{array}$ & $\begin{array}{l}\text { Two-week diary } \\
\text { plus receipts }\end{array}$ & Fineli \\
\hline Italy & $\begin{array}{l}\text { Multi-purpose } \\
\text { Survey on Daily } \\
\text { Life }\end{array}$ & $\begin{array}{l}\text { Individual, } \\
\text { cross-sectional }\end{array}$ & $\begin{array}{l}\text { Nationally for } \\
\text { whole } \\
\text { population }\end{array}$ & 2009 & $\begin{array}{l}\text { Individuals aged } \\
\geq 50 \text { years } \\
\text { living in } \\
\text { one- and } \\
\text { two-person } \\
\text { households }\end{array}$ & 7564 & $\begin{array}{l}\text { Food frequency, } \\
16 \text { aggregate food } \\
\text { categories } \\
\text { (bakery products, } \\
\text { processed meats, } \\
\text { poultry, beef, } \\
\text { pork, milk, dairy } \\
\text { products, eggs, } \\
\text { fish, leaf } \\
\text { vegetables, other } \\
\text { vegetables, fruit, } \\
\text { pulses, potatoes, } \\
\text { salted snacks, } \\
\text { confectionery }\end{array}$ & $\begin{array}{l}\text { Questionnaire, } \\
\text { face-to-face } \\
\text { interviews }\end{array}$ & $\begin{array}{l}\text { Italian National } \\
\text { Institute for } \\
\text { Research on } \\
\text { Food and } \\
\text { Nutrition }\end{array}$ \\
\hline Sweden & $\begin{array}{l}\text { Swedish National } \\
\text { Survey on Aging } \\
\text { and Care } \\
\text { (SNAC-K) }\end{array}$ & $\begin{array}{l}\text { Individual, } \\
\text { cross-sectional }\end{array}$ & $\begin{array}{l}\text { Community- } \\
\text { based } \\
\text { population }\end{array}$ & 2001-2004 & $\begin{array}{l}\text { Age } \geq 60 \text { years, } \\
\text { living either at } \\
\text { home or } \\
\text { institutions }\end{array}$ & 2023 & $\begin{array}{l}\text { Semi-quantitative } \\
\text { FFQ }\end{array}$ & $\begin{array}{l}\text { Self-administered } \\
\text { at first visit }\end{array}$ & $\begin{array}{l}\text { National Food } \\
\text { Composition } \\
\text { database, using } \\
\text { the software } \\
\text { MATS (Rudans } \\
\text { Lättdata, Västerå, } \\
\text { Sweden) }\end{array}$ \\
\hline
\end{tabular}


Table 3 Determinants of diet quality in the UK

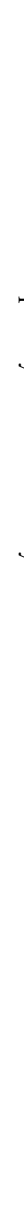

E\%, percentage of energy; CHO, carbohydrate; F\&V, fruits and vegetables; DQI, Diet Quality Index; CU, consumption unit; ref., reference category.

${ }^{* \star *}$ Statistically significant at $1 \%$ level; ** ${ }^{*}$ statistically significant at $5 \%$ level; "statistically significant at $10 \%$ level; coefficients of regional dummy variables not reported. 
Table 3 corresponding to those having achieved at most a primary level of education).

5. The definition of socio-professional categories varies across countries but the reference group used to build the dummy variables corresponds to pensioners. The Swedish data set differs from the others in that it only covers individuals over the age of 60 years who are almost all pensioners and, in that case, socioprofessional category refers to the pre-retirement status.

6. Household structure is described by a dummy variable distinguishing those living alone from others (the reference category in Table 3 being couples).

7. The gender dummy in Table 3 takes males as the reference group.

8. To allow for potentially non-linear relationships, age enters the model through dummies for 5-year age brackets, the reference corresponding to the youngest age group.

9. Regional and quarterly dummies are also introduced. For the latter, the fourth quarter is taken as reference for comparison.

10. In the two data sets with repeated cross-sections, a year dummy is also introduced.

\section{Results}

On the basis of the calculated index, diet quality of the elderly in the four countries is both relatively poor and heterogeneous. From a maximum achievable score of 80 , the mean score in the sample is 50 in Sweden, 36 in Finland and 60 in the UK, with few individuals achieving the maximum score. The distributions of the index in the four samples are in each case wide, indicating that diet quality varies greatly within each population. However, a closer look at the sub-components of the DQI reveals that the nutritional problems underlying the relatively low DQI scores are not necessarily the same across countries. In Finland, excess consumption of salt and saturated fat appears particularly problematic, while underconsumption of fruits and vegetables represents a larger problem in Sweden.

Next, the regression analysis seeks to explain variation in diet quality within each sample by sociodemographic variables. The full regression results are presented in Tables 3-6 separately for each country. In all four countries, several sociodemographic variables explain diet quality of the elderly in a statistically significant manner, but the overall explanatory power of the models remains modest: the $R^{2}$ statistic varies from $4 \%$ for the UK and Italy to $10 \%$ for Sweden and Finland. The low explanatory power of the models, which is not unusual given the cross-sectional nature of the data, could be caused by measurement errors, the omission of important variables or inherent and unobserved heterogeneity (for instance related to tastes). However, we also note that, for all four countries, total energy consumption is much better explained than diet quality. One potential reason is that diet quality affects well-being (i.e. what economists call 'utility') only indirectly, while the choice of energy intake, which determines satiation of hunger, has a more direct impact on utility. Previous authors have used a similar argument to explain why models of demand for macronutrients usually perform much better than corresponding models for micronutrients ${ }^{(13,14)}$.

However, we also note similarities across the four countries in the way that each sociodemographic variable associates with diet quality. In the UK and Finland, the coefficient of the variable 'resource availability' is significant at the $1 \%$ level but the direction of the effect is unexpected: relatively better-off households adopt, ceteris paribus, diets of relatively poorer quality. The result is explained mainly by a greater share of energy derived from fat and saturated fat and the larger consumption of cholesterol and sodium as total expenditure increases. Those changes influence diet quality negatively and dominate the positive effect of an increase in the consumption of fruits, vegetables and calcium as expenditure rises. For the other two countries, the resource constraint is not found to be significant (Sweden) or monotonically associated with diet quality (Italy) but we note that in both cases, the variable is self-assessed and measured imperfectly.

The variable 'preference for food' defined in the previous section is also very significantly and negatively associated with diet quality in the two samples that allow its measurement (corresponding to the UK and Finland). Hence, elderly households that allocate relatively more of their resources to food consumption, holding total expenditure constant, achieve a relatively lower DQI. The explanation lies mainly with a larger share of energy derived from fat and an increase in the consumption of cholesterol as the share of expenditure allocated to food expands. The qualitative variables used to measure resource availability in Italy and Sweden do not permit the construction of a comparable variable measuring the elderly's preference for food.

Next, the association between education and diet quality is investigated. Taking individuals having at most completed primary school as a reference, it is found in all four countries that achieving a tertiary level of education is associated with higher diet quality. In the case of Italy, the result extends to secondary education. Hence, there is evidence that the better-educated elderly make healthier food choices and that the effect is not due to the correlates of education, such as higher income, which are controlled for. Although the exact underlying mechanisms seem different in the four samples, the relatively higher consumption of fruits and vegetables of the more-educated elderly emerges in all four countries and, in the two Nordic countries, the analysis also reveals that education is associated with lower consumption of saturated fat. 
Table 4 Determinants of diet quality in Italy

\begin{tabular}{|c|c|c|c|c|c|c|c|c|c|c|c|c|c|c|c|c|}
\hline & \multicolumn{10}{|c|}{ Macronutrients } & \multicolumn{6}{|c|}{ Other } \\
\hline & \multicolumn{2}{|c|}{ Total energy, $\log ()}$. & \multicolumn{2}{|c|}{ Total fat $(\mathrm{E} \%)$} & \multicolumn{2}{|c|}{ Saturated fat $(E \%)$} & \multicolumn{2}{|c|}{ Protein, $\log ()}$. & \multicolumn{2}{|c|}{$\mathrm{CHO}(\mathrm{E} \%)$} & \multicolumn{2}{|c|}{ Cholesterol, log(.) } & \multicolumn{2}{|c|}{ F\&V portions } & \multicolumn{2}{|c|}{$\mathrm{RCl}$} \\
\hline & $\beta$ & SE & $\beta$ & $\mathrm{SE}$ & $\beta$ & SE & $\beta$ & $\mathrm{SE}$ & $\beta$ & SE & $\beta$ & SE & $\beta$ & SE & $\beta$ & $\mathrm{SE}$ \\
\hline $\begin{array}{l}\text { Constant } \\
\text { Financial resources (ref. Insufficient) }\end{array}$ & $3 \cdot 158^{\star \star \star}$ & 0.009 & $20 \cdot 819^{\star \star \star}$ & 0.366 & $9 \cdot 996^{\star \star \star}$ & $0 \cdot 211$ & $2 \cdot 452^{\star \star}$ & 0.010 & $59 \cdot 296^{\star \star *}$ & 0.511 & $2 \cdot 305^{\star \star \star}$ & 0.025 & $2 \cdot 299^{\star \star \star}$ & $0 \cdot 105$ & $0 \cdot 715^{*}$ & 0.008 \\
\hline Poor & $0.026^{\star \star \star}$ & 0.007 & $0.557^{\star \star}$ & 0.257 & $0.281^{*}$ & $0 \cdot 148$ & $0.029^{\star \star \star}$ & 0.007 & $-0.654^{\star}$ & 0.359 & $0.055^{\star \star \star}$ & $0 \cdot 018$ & 0.093 & 0.074 & $0 \cdot 011^{*}$ & 0.006 \\
\hline Adequate & $0.032^{\star \star \star}$ & 0.007 & $0.824^{\star \star \star}$ & 0.257 & $0 \cdot 441^{\star \star \star}$ & $0 \cdot 148$ & $0.036^{\star \star}$ & 0.007 & $-0.940^{\star \star \star}$ & 0.358 & $0 \cdot 070^{\star \star \star}$ & $0 \cdot 018$ & $0.262^{\star \star \star}$ & 0.074 & $0.024^{\star \star}$ & 0.006 \\
\hline Very good & $0.031^{*}$ & 0.016 & $1 \cdot 239^{\star \star}$ & 0.615 & 0.552 & $0 \cdot 354$ & $0 \cdot 047^{\star \star \star}$ & 0.016 & $1 \cdot 921^{\star *}$ & 0.857 & $0 \cdot 099^{\star \star}$ & 0.042 & $0 \cdot 129$ & $0 \cdot 176$ & 0.015 & $0 \cdot 014$ \\
\hline \multicolumn{17}{|l|}{ Household type (ref. Couple) } \\
\hline Male alone & $0 \cdot 017^{\star \star \star}$ & 0.004 & -0.241 & $0 \cdot 165$ & $-0 \cdot 194^{\star \star}$ & 0.095 & $0.020^{\star * \star}$ & 0.004 & 0.051 & 0.230 & $0.020^{*}$ & $0 \cdot 011$ & $-0.366^{\star *}$ & 0.047 & $-0 \cdot 025^{\star}$ & 0.004 \\
\hline Female alone & $-0 \cdot 060^{\star \star \star}$ & 0.004 & $0.338^{\star \star}$ & $0 \cdot 137$ & $0 \cdot 250^{\star \star \star}$ & 0.079 & $-0.068^{\star \star}$ & 0.004 & 0.071 & $0 \cdot 191$ & $-0.069^{\star \star *}$ & 0.009 & -0.030 & 0.039 & $-0.009^{\star}$ & 0.003 \\
\hline \multicolumn{17}{|l|}{ Education (ref. Primary) } \\
\hline Secondary & $0.011^{\star \star \star}$ & 0.003 & $0.339^{* \star *}$ & $0 \cdot 124$ & $0 \cdot 140^{\star}$ & 0.071 & $10 \cdot 013^{\star \star \star}$ & 0.003 & $-0.419^{\star \star}$ & 0.172 & $0 \cdot 018^{\star \star}$ & 0.009 & $0 \cdot 198^{\star * *}$ & 0.035 & $0.015^{\star *}$ & 0.003 \\
\hline Tertiary & -0.008 & 0.006 & $0 \cdot 650^{\star \star \star}$ & 0.240 & $0 \cdot 289^{\star \star}$ & $0 \cdot 138$ & -0.004 & 0.006 & $-0 \cdot 845^{\star \star}$ & 0.335 & $-0.030^{\star}$ & 0.017 & $0.462^{\star \star \star}$ & 0.069 & $0.029^{* *}$ & 0.006 \\
\hline \multicolumn{17}{|l|}{ Employment (ref. Retired) } \\
\hline Self-employed & 0.006 & 0.006 & $0.662^{\star \star \star}$ & 0.214 & $0 \cdot 298^{\star \star}$ & 0.123 & $0.011^{*}$ & 0.006 & $-0.890^{* * *}$ & 0.299 & 0.018 & 0.015 & -0.002 & 0.061 & -0.000 & 0.005 \\
\hline Manager & -0.009 & 0.011 & $0 \cdot 784^{\star}$ & 0.427 & $0.432^{\star}$ & 0.246 & -0.005 & 0.011 & -0.928 & 0.596 & 0.012 & 0.030 & $-0.371^{\star \star}$ & $0 \cdot 122$ & $-0.029^{\star}$ & 0.010 \\
\hline Employee & $-0 \cdot 017^{\star \star \star}$ & 0.005 & $0.665^{\star \star \star}$ & $0 \cdot 175$ & $0 \cdot 344^{\star \star \star}$ & $0 \cdot 100$ & $-0.016^{\star \star}$ & 0.005 & $-0.672^{\star \star \star}$ & 0.243 & $-0.023^{\star}$ & 0.012 & $-0.123^{\star \star}$ & 0.050 & $-0.013^{\star}$ & 0.004 \\
\hline \multicolumn{17}{|l|}{ Age (ref. 50-54 years) } \\
\hline $55-60$ years & $-0 \cdot 018^{\star \star \star}$ & 0.006 & -0.392 & 0.250 & -0.089 & $0 \cdot 144$ & -0.011 & 0.007 & 0.019 & 0.349 & -0.023 & $0 \cdot 017$ & $0 \cdot 129^{\star}$ & 0.072 & 0.008 & 0.006 \\
\hline $60-65$ years & $-0.012^{*}$ & 0.007 & $-0.600^{\star \star}$ & 0.256 & $-0 \cdot 124$ & $0 \cdot 147$ & -0.003 & 0.007 & $0 \cdot 151$ & 0.357 & -0.021 & 0.018 & $0 \cdot 146^{\star \star}$ & 0.073 & 0.010 & 0.006 \\
\hline $65-70$ years & $-0 \cdot 015^{\star \star}$ & 0.007 & $-0.666^{\star \star}$ & 0.263 & 0.069 & $0 \cdot 151$ & 0.003 & 0.007 & -0.187 & 0.367 & -0.016 & 0.018 & 0.122 & 0.075 & 0.008 & 0.006 \\
\hline $70-75$ years & $-0.012^{*}$ & 0.007 & $-0.981^{\star \star \star}$ & 0.271 & -0.216 & $0 \cdot 156$ & 0.002 & 0.007 & 0.360 & 0.379 & -0.009 & 0.019 & 0.088 & 0.078 & 0.007 & 0.006 \\
\hline $75-80$ years & $-0.014^{\star}$ & 0.007 & $-0.581^{\star \star}$ & 0.279 & 0.058 & $0 \cdot 161$ & 0.000 & 0.007 & -0.097 & 0.389 & -0.014 & 0.019 & 0.011 & 0.080 & -0.000 & 0.006 \\
\hline$>80$ years & $-0.017^{\star *}$ & 0.007 & $-0.754^{\star \star \star}$ & 0.278 & 0.062 & $0 \cdot 160$ & -0.002 & 0.007 & 0.002 & 0.388 & $-0.033^{\star}$ & 0.019 & -0.092 & 0.080 & -0.010 & 0.006 \\
\hline \multicolumn{17}{|l|}{ Region (ref. North-West) } \\
\hline North-East & 0.004 & 0.004 & -0.043 & $0 \cdot 154$ & 0.031 & 0.088 & 0.003 & 0.004 & 0.080 & $0 \cdot 214$ & 0.002 & 0.011 & $0 \cdot 103^{* *}$ & 0.044 & $0.009^{* *}$ & 0.004 \\
\hline Central & 0.002 & 0.004 & $-1 \cdot 498^{\star \star \star}$ & $0 \cdot 164$ & $-0 \cdot 886^{\star \star \star}$ & 0.095 & 0.001 & 0.004 & $1 \cdot 490^{\star \star *}$ & 0.229 & -0.009 & 0.011 & 0.062 & 0.047 & $0.011^{\star \star}$ & 0.004 \\
\hline South & $-0.015^{\star \star \star}$ & 0.004 & $-1 \cdot 826^{\star \star \star}$ & $0 \cdot 155$ & $-1 \cdot 034^{\star \star \star}$ & 0.089 & $-0.018^{\star *}$ & 0.004 & $1.975^{\text {***}}$ & 0.216 & $-0.025^{\star *}$ & 0.011 & $-0.311^{\star *}$ & 0.044 & $-0.020^{\star *}$ & 0.004 \\
\hline Islands & -0.007 & 0.006 & $-1 \cdot 748^{\star \star \star}$ & 0.213 & $-0.878^{\star \star \star}$ & 0.123 & -0.008 & 0.006 & $1 \cdot 813^{\star \star \star}$ & 0.297 & -0.013 & 0.015 & $-0.153^{\star \star}$ & 0.061 & $-0.008^{\star}$ & 0.005 \\
\hline$R^{2}$ & $6 \cdot 3 \%$ & & $5.0 \%$ & & $4.2 \%$ & & $7 \cdot 7 \%$ & & $2.5 \%$ & & $1.6 \%$ & & $4.5 \%$ & & $3.9 \%$ & $\%$ \\
\hline
\end{tabular}

E\%, percentage of energy; $\mathrm{CHO}$, carbohydrate; F\&V, fruits and vegetables; RCI, Recommendation Compliance Index; ref., reference category.

${ }^{* * *}$ Statistically significant at $1 \%$ level; ** ${ }^{*}$ statistically significant at $5 \%$ level; * ${ }^{2}$ statistically significant at $10 \%$ level. 
Table 5 Determinants of diet quality in Finland

\begin{tabular}{|c|c|c|c|c|c|c|c|c|c|c|c|c|c|c|c|c|c|c|c|c|}
\hline & \multicolumn{10}{|c|}{ Macronutrients } & \multicolumn{10}{|c|}{ Other } \\
\hline & \multicolumn{2}{|c|}{ Total energy, $\log ()}$. & \multicolumn{2}{|c|}{ Total fat (E\%) } & \multicolumn{2}{|c|}{ Saturated fat (E\%) } & \multicolumn{2}{|c|}{ Protein, $\log ()}$. & \multicolumn{2}{|c|}{$\mathrm{CHO}(\mathrm{E} \%)$} & \multicolumn{2}{|c|}{ Cholesterol, log(.) } & \multicolumn{2}{|c|}{ Sodium, log(.) } & \multicolumn{2}{|c|}{ Calcium, log(.) } & \multicolumn{2}{|c|}{$F \& V, \log ()}$. & \multicolumn{2}{|l|}{ DQI } \\
\hline & $\beta$ & SE & $\beta$ & SE & $\beta$ & SE & $\beta$ & SE & $\beta$ & SE & $\beta$ & SE & $\beta$ & SE & $\beta$ & SE & $\beta$ & SE & $\beta$ & SE \\
\hline Constant & -0.380 & 0.318 & $0.238^{\star * *}$ & 0.041 & $0.098^{\star \star \star}$ & 0.021 & $-3 \cdot 860^{\star \star \star}$ & 0.330 & $0.578^{\star \star \star}$ & 0.043 & $-2 \cdot 750^{\star \star \star}$ & 0.372 & $-0.980^{*}$ & 0.560 & $-0 \cdot 070$ & 0.348 & $-3 \cdot 390^{\star \star \star *}$ & 0.359 & $123 \cdot 200^{\star \star \star}$ & $6 \cdot 875$ \\
\hline Log (total expenditure/CU) & $0.749^{\star \star *}$ & 0.031 & $0.011^{\star * *}$ & 0.004 & $0.004^{\star \star}$ & 0.002 & $0 \cdot 770^{\star \star \star}$ & 0.032 & $-0 \cdot 010^{\star \star \star}$ & 0.004 & $0.787^{\star \star \star}$ & 0.036 & $0.821^{\star * *}$ & 0.054 & $0.648^{\star * *}$ & 0.034 & & 0.035 & $-8 \cdot 020^{\star \star \star}$ & 0.673 \\
\hline \multicolumn{7}{|l|}{ Household type (ref. Couple) } & & 0.179 & -0.020 & 0.023 & $5 \cdot 282^{\star \star \star}$ & 0.202 & $4 \cdot 880^{\star \star *}$ & 0.299 & $4 \cdot 280^{\star \star \star}$ & $0 \cdot 187$ & $4 \cdot 526^{\star \star \star}$ & 0.191 & $-52 \cdot 900^{\star \star \star}$ & 3.634 \\
\hline Male alone & $0 \cdot 121^{\star \star \star}$ & 0.037 & -0.000 & 0.004 & $-0.000^{*}$ & 0.002 & $0 \cdot 129^{\star \star \star}$ & 0.038 & 0.004 & 0.005 & $0 \cdot 117^{\star \star \star}$ & 0.043 & 0.058 & 0.066 & 0.026 & 0.040 & $-0 \cdot 110^{\star \star \star}$ & 0.042 & $-2 \cdot 040^{* *}$ & 0.832 \\
\hline $\begin{array}{l}\text { Female alone } \\
\text { Education (ref. Primary) }\end{array}$ & $0 \cdot 119^{\star \star \star}$ & 0.028 & -0.000 & 0.003 & -0.000 & 0.001 & $0.087^{\star \star \star}$ & 0.029 & 0.006 & 0.003 & $0.139^{\star \star \star}$ & 0.032 & -0.000 & 0.050 & $0.118^{\star \star \star}$ & 0.030 & $0 \cdot 195^{\star \star \star}$ & 0.031 & $-1 \cdot 390^{\star *}$ & 0.622 \\
\hline Secondary & 0.033 & 0.028 & -0.000 & 0.003 & $-0.000^{*}$ & 0.001 & $0.059^{\star \star}$ & 0.029 & 0.003 & 0.003 & 0.011 & 0.033 & 0.046 & 0.050 & $0.055^{\star}$ & 0.031 & $0.076^{\star *}$ & 0.032 & 0.785 & 0.636 \\
\hline $\begin{array}{l}\text { Tertiary } \\
\text { Social group (ref. Pensioner) }\end{array}$ & -0.030 & 0.031 & -0.000 & 0.004 & $-0.000^{\star \star *}$ & 0.002 & -0.030 & 0.032 & -0.000 & 0.004 & $-0.060^{*}$ & 0.036 & -0.030 & 0.056 & -0.010 & 0.034 & $0.090^{* \star}$ & 0.035 & $1 \cdot 785^{\star \star}$ & 0.700 \\
\hline Entrepreneur & 0.047 & 0.051 & -0.000 & 0.006 & 0.001 & 0.003 & 0.039 & 0.052 & 0.007 & 0.007 & 0.056 & 0.059 & 0.051 & 0.090 & 0.050 & 0.056 & 0.028 & 0.057 & 0.773 & $1 \cdot 131$ \\
\hline & -0.05 & & & & & & & 0.0 & 0.003 & 0.00 & $-0 \cdot 150^{\star \star \star}$ & & -0.070 & 0.073 & $-0.080^{*}$ & & & & & \\
\hline Blue collar & 0.052 & 0.046 & 0.007 & 0.006 & 0.002 & 0.003 & 0.006 & 0.048 & -0.000 & 0.00 & -0.000 & & & 0.082 & & 0.050 & -0.0 & & $-1 \cdot 110$ & $1 \cdot 034$ \\
\hline $\begin{array}{l}\text { Other } \\
\text { Age (ref } 50-5\end{array}$ & $0 \cdot 165^{\star \star \star}$ & 0.062 & -0.000 & 0.008 & -0.000 & 0.004 & $0 \cdot 147^{\star \star}$ & 0.064 & 0.001 & 0.008 & $0.123^{*}$ & 0.072 & $0 \cdot 327^{\star \star \star}$ & $0 \cdot 111$ & $0 \cdot 145^{\star \star}$ & 0.067 & 0.072 & 0.070 & -0.380 & $1 \cdot 390$ \\
\hline $55-6$ & 0.047 & 0.040 & 0.002 & 0.005 & -0.000 & 0.002 & 0.018 & 0.042 & -0.000 & 0.005 & -0.040 & 0.047 & \multicolumn{7}{|c|}{ Age (ref. } & \\
\hline $60-65$ years & $0 \cdot 106^{\star \star}$ & 0.043 & 0.001 & 0.005 & -0.000 & 0.002 & 0.06 & 0.045 & 0.003 & 0.005 & -0.020 & 0.05 & 0.09 & 0.077 & 0.0 & 0.0 & $0.148^{\star \star \star}$ & 0.0 & 1.0 & 0.968 \\
\hline $65-70$ & & 0.0 & -0.00 & 0.0 & -0.000 & & & 0.0 & 0.0 & 0.0 & & 0.6 & 0.1 & 0.0 & & 0.0 & $5^{\star \star \star}$ & 0.05 & $1 \cdot 4$ & 1.129 \\
\hline $70-7$ & & & -0.00 & & 0.0 & & & 0.0 & 0.008 & 0.0 & 0.016 & & & 0.0 & & 0.0 & 0.0 & 0.6 & $1 \cdot 7$ & 1.191 \\
\hline $75-80$ y & $0 \cdot 110^{\star}$ & 0.05 & $-0.010^{\star}$ & 0.007 & $-0 \cdot 000$ & 0.00 & & 0.058 & $0.022^{\star \star \star}$ & 0.007 & -0.060 & 0.0 & 0.05 & 0.1 & 0.0 & 0.06 & 0.020 & 0.0 & $3 \cdot 251^{\star \star}$ & $1 \cdot 271$ \\
\hline \multirow{2}{*}{\multicolumn{21}{|c|}{ Year (ref. 2007) }} \\
\hline & & & & & & & & & & & & & & & & & & & & \\
\hline \multicolumn{21}{|l|}{ Quarter (ref. Quarter 4) } \\
\hline Quarter 1 & $0.068^{\star \star}$ & 0.031 & $-0.000^{\star}$ & 0.004 & $-0.000^{\star \star}$ & 0.002 & $0.074^{\star \star}$ & 0.032 & $0 \cdot 007^{\star}$ & 0.004 & 0.015 & 0.035 & 0.086 & 0.055 & $0.074^{\star \star}$ & 0.033 & $0.096^{\star \star \star}$ & 0.034 & $1 \cdot 401^{\star \star}$ & 0.686 \\
\hline & 0.037 & 0.02 & & 0.003 & $-0.000^{* \star \star}$ & 0.001 & 0.009 & 0.030 & $0.011^{\star \star \star}$ & 0.004 & $-0.050^{*}$ & 0.034 & $0 \cdot 112^{\star \star}$ & 0.052 & 0.000 & 0.032 & 0.020 & 0.033 & $1 \cdot 262^{*}$ & 0.659 \\
\hline arter 3 & $0.095^{\star \star \star}$ & 0.030 & $-0.010^{\star \star \star}$ & 0.003 & $-0 \cdot 000^{* *}$ & 0.002 & .041 & 0.031 & $0.013^{\star \star \star}$ & 0.004 & -0.010 & 0.035 & $0 \cdot 162^{\star \star \star}$ & 0.054 & $0.062^{*}$ & 0.033 & 0.050 & 0.034 & $1 \cdot 740^{\star \star}$ & 0.678 \\
\hline \multicolumn{21}{|l|}{ Region (ref. South) } \\
\hline $\begin{array}{l}\text { West } \\
\text { East }\end{array}$ & $\begin{array}{l}-0.010 \\
-0.000\end{array}$ & $\begin{array}{l}0.027 \\
0.032\end{array}$ & $\begin{array}{l}-0.000 \\
-0.010^{\star \star \star}\end{array}$ & $\begin{array}{l}0.003 \\
0.004\end{array}$ & $\begin{array}{r}0.001 \\
-0.000\end{array}$ & $\begin{array}{l}0.001 \\
0.002\end{array}$ & $\begin{array}{l}-0.040 \\
-0.000\end{array}$ & $\begin{array}{l}0.028 \\
0.033\end{array}$ & $\begin{array}{l}0.004 \\
0.006\end{array}$ & $\begin{array}{l}0.003 \\
0.004\end{array}$ & $\begin{array}{r}-0.010 \\
0.030\end{array}$ & $\begin{array}{l}0.031 \\
0.037\end{array}$ & $\begin{array}{l}-0.120^{\star \star} \\
-0.080\end{array}$ & $\begin{array}{l}0.048 \\
0.057\end{array}$ & $\begin{array}{r}-0.010 \\
0.020\end{array}$ & $\begin{array}{l}0.029 \\
0.035\end{array}$ & $\begin{array}{l}0.023 \\
0.099^{* * *}\end{array}$ & $\begin{array}{l}0.030 \\
0.036\end{array}$ & $\begin{array}{l}0.065 \\
1.225^{*}\end{array}$ & $\begin{array}{l}0.608 \\
0.720\end{array}$ \\
\hline North & -0.010 & 0.037 & $-0.010^{\star \star \star}$ & 0.004 & -0.000 & & 0.019 & 0.038 & 0.005 & 0.00 & -0.010 & 0.04 & -0.060 & 0.066 & 0.062 & 0.041 & -0.000 & & $1.916^{\star *}$ & 0.832 \\
\hline$R^{\text {Aland }}$ & $-0 \cdot 100$ & 0.066 & -0.000 & 0.008 & 0.002 & 0.004 & $\begin{array}{l}-0.090 \\
26 .\end{array}$ & 0.069 & -0.000 & 0.009 & 0.034 & 0.077 & -0.190 & 0.118 & $\begin{array}{l}-0 \cdot 100 \\
19 .\end{array}$ & 0.072 & 0.063 & 0.075 & $1 \cdot 400$ & $1 \cdot 480$ \\
\hline
\end{tabular}

$\mathrm{E} \%$, percentage of energy; $\mathrm{CHO}$, carbohydrate; F\&V, fruits and vegetables; DQI, Diet Quality Index; CU, consumption unit; ref., reference category.

${ }^{* * *}$ Statistically significant at $1 \%$ level; ** statistically significant at $5 \%$ level; *statistically significant at $10 \%$ level. 
Table 6 Determinants of diet quality in Sweden

\begin{tabular}{|c|c|c|c|c|c|c|c|c|c|c|c|c|c|c|c|c|c|c|c|c|}
\hline $\begin{array}{l}\text { Constant } \\
\text { Difficulty in }\end{array}$ & $7 \cdot 485^{\star \star \star}$ & 0.072 & $34 \cdot 406^{\star \star \star}$ & 1.477 & $13 \cdot 457^{\star \star \star}$ & 0.772 & $4 \cdot 080^{\star \star \star}$ & 0.083 & $40 \cdot 806^{\star \star \star}$ & * 1.627 & $5 \cdot 351^{\star \star \star}$ & $0 \cdot 100$ & $7 \cdot 750^{\star \star \star}$ & 0.085 & $6 \cdot 716^{* \star *}$ & 0.101 & $1 \cdot 381^{* \star *}$ & 0.119 & $41 \cdot 688^{\star \star \star}$ & $2 \cdot 800$ \\
\hline $\begin{array}{l}\text { Difflculty in taking care } \\
\text { No }\end{array}$ & 0.0004 & 0.034 & $-1 \cdot 257^{\star}$ & 0.697 & $-0 \cdot 648^{*}$ & 0.364 & 0.011 & 0.039 & $1 \cdot 900^{\star *}$ & 0.768 & -0.040 & 0.047 & -0.028 & 0.040 & -0.061 & 0.047 & 0.032 & 0.056 & $1 \cdot 789$ & $1 \cdot 323$ \\
\hline Age (ref. 60-65 years) & & & & & & & & & & & & & & & & & & & & \\
\hline $\begin{array}{l}65-70 \text { years } \\
70-75 \text { years }\end{array}$ & $\begin{array}{l}0.051^{\star \star \star} \\
0.076^{\star \star \star}\end{array}$ & $\begin{array}{l}0.019 \\
0.021\end{array}$ & $\begin{array}{r}-0.269 \\
0.564\end{array}$ & $\begin{array}{l}0.402 \\
0.438\end{array}$ & $\begin{array}{l}-0.057 \\
0.556^{* \star}\end{array}$ & $\begin{array}{l}0.210 \\
0.229\end{array}$ & $\begin{array}{l}0.033 \\
0.051^{* *}\end{array}$ & $\begin{array}{l}0.022 \\
0.024\end{array}$ & $\begin{array}{l}0.714 \\
0.181\end{array}$ & $\begin{array}{l}0.445 \\
0.480\end{array}$ & $\begin{array}{l}0 \cdot 058^{* *} \\
0.071^{* *}\end{array}$ & $\begin{array}{l}0.027 \\
0.029\end{array}$ & $0 \cdot 047^{\star \star}$ & $\begin{array}{l}0.023 \\
0.025\end{array}$ & $\begin{array}{l}0.058^{\star \star} \\
0.138^{\star \star \star}\end{array}$ & 0.027 & -0.003 & 0.033 & -0.291 & 0.773 \\
\hline $\begin{array}{l}70-75 \text { years } \\
75-80 \text { years }\end{array}$ & $\begin{array}{l}0.076^{\star \star n \star x} \\
0.085^{\star \star \star}\end{array}$ & $\begin{array}{l}0.021 \\
0.023\end{array}$ & $\begin{array}{l}0.564 \\
0.329\end{array}$ & $\begin{array}{l}0.438 \\
0.479\end{array}$ & $\begin{array}{l}0.556^{\star *} \\
0.551^{\star *}\end{array}$ & $\begin{array}{l}0.229 \\
0.250\end{array}$ & $\begin{array}{l}0.0511^{\pi x} \\
0.040\end{array}$ & $\begin{array}{l}0.024 \\
0.026\end{array}$ & $\begin{array}{l}0.181 \\
0.983^{*}\end{array}$ & $\begin{array}{l}0.480 \\
0.527\end{array}$ & $\begin{array}{l}0.071^{\star \pi} \\
0.054^{*}\end{array}$ & $\begin{array}{l}0.029 \\
0.032\end{array}$ & $\begin{array}{l}0.063^{* x} \\
0.050^{*}\end{array}$ & $\begin{array}{l}0.025 \\
0.027\end{array}$ & $\begin{array}{l}0.1388^{* * *} \\
0.130^{* * *}\end{array}$ & $\begin{array}{l}0.030 \\
0.033\end{array}$ & $\begin{array}{c}-0.0004 \\
0.017\end{array}$ & $\begin{array}{l}0.035 \\
0.039\end{array}$ & $\begin{array}{l}-1.121 \\
-0.721\end{array}$ & $\begin{array}{l}0.836 \\
0.912\end{array}$ \\
\hline Sex (ref. Male) & & & & & & & & & & & & & & & & & & & & \\
\hline $\begin{array}{l}\text { Female } \\
\text { Education (ref. University) }\end{array}$ & $-0 \cdot 228^{\star \star \star}$ & 0.016 & $-3 \cdot 040^{\star \star \star}$ & 0.329 & $-0.987^{\star \star *}$ & $0 \cdot 172$ & $-0 \cdot 162^{\star \star \star}$ & $0 \cdot 018$ & $4 \cdot 122^{\star \star \star}$ & * 0.363 & $-0 \cdot 209^{\star \star \star}$ & 0.022 & $-0 \cdot 246^{\star \star \star}$ & 0.019 & $-0 \cdot 106^{\star \star \star}$ & 0.022 & $0.236^{\star \star *}$ & 0.026 & $7 \cdot 232^{\star \star \star}$ & 0.629 \\
\hline $\begin{array}{l}\text { High school } \\
\text { Flementary }\end{array}$ & $-0.059^{\star \star \star}$ & 0.0 & 0.552 & 0.343 & $0.390^{\star \star}$ & 0.179 & $-0.054^{\star \star \star}$ & 0.019 & -0.113 & 0.378 & -0.027 & 0.023 & $-0.042^{\star *}$ & 0.019 & $-0.072^{\star \star \star}$ & 0.023 & $-0.081^{\star \star \star *}$ & 0.028 & -0.617 & 0.656 \\
\hline $\begin{array}{l}\text { Elementary } \\
\text { Civil status (ref. Married) }\end{array}$ & -0.016 & 0.02 & $\cdot 930^{\star \star \star}$ & 0.577 & $1 \cdot 183^{\star \star \star}$ & 0.302 & -0.008 & 0.032 & 0.046 & 0.634 & 0.015 & 0.039 & 0.019 & 0.033 & -0.020 & 0.040 & $-0 \cdot 119^{\star \star}$ & 0.047 & $-2 \cdot 191^{\star *}$ & $1 \cdot 105$ \\
\hline $\begin{array}{l}\text { Unmarried } \\
\text { Widow/er }\end{array}$ & $\begin{array}{l}-0 \cdot 017 \\
-0 \cdot 070^{\star \star \star}\end{array}$ & $\begin{array}{l}0.021 \\
0.026\end{array}$ & $\begin{array}{l}-0.445 \\
-0.119\end{array}$ & $\begin{array}{l}0.433 \\
0.526\end{array}$ & $\begin{array}{l}0.023 \\
0.035\end{array}$ & $\begin{array}{l}0.226 \\
0.275\end{array}$ & $\begin{array}{l}-0.004 \\
-0.081^{\star \star \star}\end{array}$ & $\begin{array}{l}0.024 \\
0.029\end{array}$ & $\begin{array}{l}0.827^{\star} \\
0.672\end{array}$ & $\begin{array}{l}0.480 \\
0.579\end{array}$ & $\begin{array}{l}-0.008 \\
-0.067^{\star}\end{array}$ & $\begin{array}{l}0.029 \\
0.035\end{array}$ & $\begin{array}{l}0.006 \\
-0.086^{\star \star \star}\end{array}$ & $\begin{array}{l}0.025 \\
0.030\end{array}$ & $\begin{array}{l}-0.036 \\
-0.092^{\star \star}\end{array}$ & $\begin{array}{l}0.029 \\
0.036\end{array}$ & $\begin{array}{l}-0.089^{* *} \\
-0.079^{*}\end{array}$ & $\begin{array}{l}0.035 \\
0.043\end{array}$ & $\begin{array}{r}-0.832 \\
1.003\end{array}$ & $\begin{array}{l}0.826 \\
1.006\end{array}$ \\
\hline $\begin{array}{l}\text { Divorced } \\
\text { Living depend }\end{array}$ & -0.024 & 0.022 & -0.732 & 0.461 & -0.335 & 0.241 & -0.007 & 0.026 & $1 \cdot 583^{\star \star \star}$ & * 0.509 & -0.025 & 0.031 & -0.037 & 0.026 & 0.044 & 0.031 & 0.004 & 0.038 & 0.399 & 0.886 \\
\hline $\begin{array}{l}\text { Dependent } \\
\text { Living alone (ref. No) }\end{array}$ & 0.227 & 0.219 & $2 \cdot 281$ & $4 \cdot 431$ & 1.351 & $2 \cdot 315$ & 0.232 & 0.249 & 1.429 & $4 \cdot 861$ & 0.277 & $0 \cdot 301$ & 0.163 & 0.257 & 0.224 & 0.306 & 0.319 & 0.509 & -4.018 & 8.447 \\
\hline $\begin{array}{l}\text { Living alone (ref. No) } \\
\text { Yes } \\
\text { Social group (ref. Blue collar) }\end{array}$ & 0.018 & 0.015 & -0.076 & 0.310 & 0.056 & 0.162 & 0.027 & 0.017 & 0.242 & $0 \cdot 342$ & $0.036^{*}$ & 0.021 & 0.021 & 0.018 & 0.024 & 0.021 & -0.012 & 0.025 & -0.541 & 0.594 \\
\hline White & -0.006 & 0.022 & -0.659 & 0.450 & -0.240 & 0.236 & -0.004 & 0.025 & -0.628 & 0.499 & 0.015 & 0.030 & -0.022 & 0.026 & 0.010 & 0.031 & -0.004 & & $2 \cdot 319^{\star \star \star}$ & 0.860 \\
\hline$R^{2}{ }^{\text {Entrep }}$ & $\begin{array}{l}0.015 \\
14 \cdot 5 \%\end{array}$ & 0.031 & $\begin{array}{r}-0.665 \\
6.9 \%\end{array}$ & $\%$ & $\begin{array}{l}-0.098 \\
4 \cdot 6 \%\end{array}$ & 0.336 & $\begin{array}{r}-0.0005 \\
7.0 \%\end{array}$ & & $\begin{array}{l}-1 \cdot 417^{* *} \\
10 \cdot 8\end{array}$ & & $\begin{array}{l}0.022 \\
7.0 \%\end{array}$ & 0.043 & $\begin{array}{l}-0.039 \\
12.3 \%\end{array}$ & $\%$ & $\begin{array}{l}-0.007 \\
4 \cdot 3 \%\end{array}$ & $\%$ & $\begin{array}{l}-0.023 \\
5.8 \%\end{array}$ & 0.052 & $\begin{array}{l}2 \cdot 219^{\star} \\
9 \cdot 5 \%\end{array}$ & $\%$ \\
\hline
\end{tabular}

E\%, percentage of energy; CHO, carbohydrate; F\&V, fruits and vegetables; DQI, Diet Quality Index; CU, consumption unit; ref., reference category.

${ }^{* *}$ Statistically significant at $1 \%$ level; ${ }^{* *}$ statistically significant at $5 \%$ level; * ${ }^{2}$ statistically significant at $10 \%$ level; coefficients of regional dummy variables not reported. 
The statistical results also establish that, once income and education are controlled for, the socio-professional status of the elderly does not correlate with diet quality in a clear manner. In the UK, active managers adopt relatively healthier diets than pensioners, but there is no statistically significant difference in diet quality between pensioners and the other socio-professional categories (employees, self-employed). Besides, a different relationship is observed in the Italian sample, where managers are found to choose diets of relatively poorer quality than pensioners. For Finland, none of the coefficients of the four dummy variables describing the socioprofessional status of the household is significant. The results of the regression models for the Swedish sample are interpreted slightly differently as the socioprofessional status describes the situation of the elderly person prior to retirement, with blue collar workers used as the reference group. It is found there that the elderly belonging to the white collar and entrepreneur categories make healthier food choices than those in the blue collar category.

The regression models indicate that in three of the four countries studied, household structure correlates significantly with diet quality: the elderly living alone make relatively less healthy food choices than elderly couples. The result is explained by different aspects of the diets in the three samples, with only the larger consumption of protein by those living alone showing consistency across the three countries. In Sweden, diet quality of those living alone is also found to be relatively poorer, but the effect is small and not statistically significant.

The impact of gender is most easily assessed in the Swedish sample because of the individual (rather than household) nature of the data and it is found that women make healthier food choices than men, the difference in diet quality score between the two groups being both large and statistically significant. This is explained by better nutrition in almost all dimensions of the DQI for women than for men: better macronutrient mix of the energy ingested (relatively more carbohydrate and less fat and saturated fat for women), lower intakes of cholesterol and sodium, as well as greater intakes of fruits and vegetables. The effect of gender is not systematically measurable in the data sets for the UK, Finland, and Italy, but valuable insights can nevertheless be derived by comparing the coefficients of the dummy variables for men living alone and women living alone. In all three cases, and in line with the Swedish results, this comparison leads to the conclusion that men make less healthy food choices than women. The reasons vary but, overall, there is evidence that, relative to men, elderly females tend to consume less protein, cholesterol and sodium while deriving a larger share of their energy from carbohydrate and consuming more fruits and vegetables.

Age is not statistically significant in explaining diet quality in the British, Italian and Swedish samples. In the
Finnish case, the relationship with age is not very robust either, as only the coefficient corresponding to the 75-80 years age range is significant, and we can conclude overall a limited influence of age on the healthiness of the food choices made by the elderly.

Tables 3-6 also provide information about the effect of some general control variables on diet quality. First, in all three countries where the nature of the data permits the analysis of potential regional effects, these are found to be significant. Hence, diets in the northern and eastern regions of Finland are found to be significantly healthier than in the south of the country; in Italy, the analysis indicates relatively better diets in the North-East and Central regions, and relatively more unhealthy food choices among the elderly in the South. In the UK, the diets of the elderly in London, the South-East, West Midlands, Scotland and Northern Ireland are relatively healthier than the diets adopted by the elderly in the North East. Next, the influence of seasonality is not found to be significant in the UK, but in Finland the elderly appear to make food choices of relatively poorer nutritional quality during the fourth quarter of the year. Finally, in an attempt to detect potential structural changes in food preferences among the elderly, the influence of the year of data collection is analysed. In Finland, once accounting for the other sociodemographic variables, no such fundamental difference in diet quality is found between the two rounds of the survey (1998 and 2006). In the UK, the elderly adopt relatively less healthy diets in 2007 than in 2006, but the short time span separating the two rounds of the survey does not allow us to conclude that the difference reflects a fundamental, continuous and worrying evolution.

The robustness of the results has been assessed by estimating different specifications of the model, as reported in the Appendix in the case of the Finnish model. Given the rather unexpected result of a negative relationship between resource availability and diet quality, we used several proxies to measure the former: total consumption expenditure per consumption unit and share of expenditure allocated to food (baseline model); total income per consumption unit (income model); and total expenditure alone (expenditure only model). In addition, the sample was also restricted by raising the age limit of eligible individuals to 65 years $(65+$ model $)$ and a model controlling for total energy intake per capita was also estimated (energy model). Although the explanatory power of the model varies a great deal across specifications, most results appear robust and, in particular, resource availability is found to affect diet quality negatively for all the variants of the Finnish model. The sensitivity analysis for other countries was less thorough because of data limitations - for instance, there is no income variable in any of the other data sets - but confirmed overall the robustness of the results. 


\section{Discussion and conclusion}

The finding that the variables resource availability and preference for food either influence diet quality negatively (in the case of the UK and Finland) or in a nonsignificant or non-linear way (in the case of Italy and Sweden) stands in sharp contrast with the predominant view in the public health literature that many individuals have few options but to make unhealthy food choices because of limited resources. Although not specifically for the elderly, this idea is for instance articulated by Drewnowski and Darmon ${ }^{(15)}$, who consider that obesity in the USA is largely an economic issue explained by growing disparities in income, the declining value of the minimum wage and the relatively low price of energydense but nutrient-poor foods compared with healthier alternatives. According to that logic, and given that the elderly in industrialised countries tend to have lower incomes and face a greater risk of relative poverty than the rest of the population, one would expect financial resources to influence diet quality positively among the elderly, but our analysis does not support that proposition. Instead, the empirical findings related to the resource availability, preference for food and even education variables appear more consistent with the view that poor diet quality among the elderly represents a 'challenge of affluence', as proposed by Offer ${ }^{(16)}$ to describe the disorders of self-control and lack of rationality of the choices that accompany growing prosperity.*

Albeit unexpected, this conclusion is rather encouraging regarding the potential of specific public health policies, as opposed to general economic ones, to improve the nutritional health of the elderly population. In particular, if poor diet quality results from the elderly's inability to appreciate the future benefits of healthy food choices, informational measures explaining those benefits more clearly may be successful in improving diet healthiness. This remains a hypothesis requiring further examination, however, because the data do not provide any measure of nutritional knowledge of the surveyed individuals.

We also note that other empirical results reported in the literature are consistent with a non-positive relationship between nutritional health and economic resources. For example, Cawley et al. $^{(18)}$ used a natural experiment to conclude that income had no effect on the weight of elderly Americans. For the general US population, Variyam and Blaylock $^{(19)}$ found that income was negatively associated with diet quality after controlling for other sociodemographic variables because of a link between income and preferences for convenience foods, dining out and more expensive, fat-rich foods. For the same US population, Popkin et al. ${ }^{(20)}$ compared dietary surveys from 1965 and 1996 to conclude the absence of any consistent and

* This view is summarised and extended in the book review of Oswald and Powdthavee ${ }^{(17)}$ significant effect of income on diet quality. Less surprising because of the lower development level of the country, Du et $a l^{(21)}$ found that rapid economic growth in China adversely affected diet quality. While these findings do not relate specifically to elderly Europeans, they point to the plausibility of our conclusion regarding the non-positive effect of resource availability on diet quality.

The estimations also support the view that food choices are largely set in those over the age of 50 years, perhaps as the result of habits contracted throughout life. In particular, retirement does not come out in the data as a major life event which, perhaps because of its impact on social networks or the opportunity cost of time, brings about a structural change in the elderly's food choices. Further, the fact that the age variable does not explain diet quality much suggests that the physiological and functional changes normally associated with ageing (e.g. changes in gustatory and olfactory functions, masticatory efficiency and mobility) cannot be regarded as the main drivers of diet quality among the elderly, at least at the population level.

If food choices and diet quality appear to be fairly stable in the over- $50 \mathrm{~s}$ age group, the analysis also reveals great inter-individual heterogeneity which is only partially explained by socio-economic variables. The finding that educational level, being a female and not living alone are positively associated with diet quality is largely in line with previous studies. For instance, in a European context, the Swedish case study of Gustavsson and Sidenvall ${ }^{(22)}$ found that women living alone were more likely to simplify meals and, as a result, adopt diets of relatively poor quality. Meanwhile, the UK study of Donkin et al. ${ }^{(23)}$ concluded that the salient question to explain intakes of fruits and vegetables was 'is there a woman in the household?' Although few studies have investigated the influence of education on the food choices of the elderly, our findings are also consistent with the robust 'education gradient', which describes the positive relationship between education and health for the general population ${ }^{(24)}$.

Finally, it is important to point to some limitations of the study. The secondary data sets did not provide information on some potentially important determinants of food choices and diet quality, which were consequently omitted from the analysis. For instance, it is difficult to conclude whether availability and access to healthy foods are important drivers of diet quality among the EU elderly, although the evidence related to the seasonality and age variables suggests, indirectly, otherwise. More serious is the omission of health status, which influences food choices and diet quality, as with diabetics urged by their physician to make specific dietary adjustments in order to manage their disease. Although some of the data included information on health status, the variable was nevertheless omitted because it is itself influenced by diet quality and therefore cannot be treated as an ordinary variable in multivariate regression analysis. $\uparrow$ While possible,

$\dagger$ Otherwise the results are subject to the 'ecological fallacy,'(25). 
statistical modelling of the bidirectional causal relationship between diet quality and health is difficult and left to further research.

\section{Acknowledgements}

Sources of funding: The research leading to these results has received funding from the Seventh Framework Programme (FP7/2007-2013) under grant agreement no. 266486 (NU-AGE project entitled 'New dietary strategies addressing the specific needs of elderly population for a healthy ageing in Europe'). Conflicts of interest: None. Ethics: Ethical approval was not required. Authors' contributions: The study was originally conceived by X.I., M.M. and W.B.T. X.I., N.K., M.M., L.M., G.N., W.B.T., W.X. and G.Z. contributed to the data mapping exercise. Data analysis was carried out by: N.K. and X.I. jointly for Finland; L.M. and M.M. for Italy; W.X., L.F. and B.S. for Sweden; G.Z., W.B.T. and G.N. for the UK. The common model was defined during a workshop involving X.I., M.M., G.N., W.B.T. and G.Z. X.I. wrote the first draft of the paper and modified it after receiving comments from all authors. X.I., M.M. and W.B.T. handled the first revision of the paper. Acknowledgements: The authors would like to thank other NU-AGE partners for the comments that they received on a preliminary version of the paper presented at the 2012 project annual meeting. Comments from two anonymous referees are gratefully acknowledged.

\section{References}

1. Lanzieri G (2011) The greying of the baby boomers. A century-long view of ageing in European populations. Population and social conditions. Stat Focus 23, 1-11.

2. Bonneux L, Van der Gaag N, Bijwaard G et al. (2012) Demographic epidemiologic projections of long-term care needs in selected European countries: Germany, Spain, the Netherland and Poland. European Network of Economic Policy Research Institutes, ENEPRI Policy Brief no. 8, February 2012; available at http://aei.pitt.edu/33554/

3. Horwath CC (2002) Nutrition and ageing. In Essentials of Human Nutrition, 2nd ed., pp. 551-565 [J Mann and AS Truswell editors]. New York: Oxford University Press.

4. Office of National Statistics (2012) What are the Chances of Surviving to Age 100? Statistical Bulletin, 26 March 2012. Newport: Office of National Statistics.

5. Christensen K, Doblhammer G, Rau R et al. (2009) Ageing populations: the challenges ahead. Lancet 374, 1196-1208.

6. Office of National Statistics (2011) Health Expectancies at Birth and at Age 65 in the United Kingdom, 2007-2009,
Statistical Bulletin, 31 August 2011. Newport: Office of National Statistics.

7. Shankar B, Srinivasan CS \& Irz X (2008) World Health Organization dietary norms: a quantitative evaluation of potential consumption impacts in the United States, United Kingdom and France. Rev Agric Econ 30, 151-175.

8. Thiele S, Mensik GBM \& Beitz R (2004) Determinants of diet quality. Public Health Nutr 7, 29-37.

9. Kant AK (1996) Indexes of overall diet quality: a review. J Am Diet Assoc 96, 785-791.

10. Waijers PM, Feskens EJ \& Ocké MC (2007) A critical review of predefined diet quality scores. Br J Nutr $\mathbf{9 7}$, 219-231.

11. Patterson RE, Haines PS \& Popkin BM (1994) Diet quality index: capturing a multidimensional behavior. J Am Diet Assoc 94, 57-64.

12. Mazzocchi M, Brasili C \& Sandri E (2008) Trends in dietary patterns and compliance with World Health Organization recommendations: a cross-country analysis. Public Health Nutr 11, 535-540.

13. Behrman JR (1995) Household Behaviour and Micronutrients: What We Know and What We Don't Know. Working Papers on Agricultural Strategies for Micronutrients no. 2. Washington, DC: IFPRI.

14. Liu Y \& Shankar B (2007) Will rising household incomes solve China's micronutrient deficiency problems? Econ Bull 15, 1-14.

15. Drewnowski A \& Darmon N (2005) The economics of obesity: dietary energy density and energy cost. Am J Clin Nutr 82, Suppl. 1, S265-S273.

16. Offer A (2006) The Challenge of Affluence: Self-Control and Well-Being in the United States and Britain Since 1950. Oxford: Oxford University Press.

17. Oswald AJ \& Powdthavee N (2007) Obesity, unhappiness, and the challenge of affluence: theory and evidence. Book review of Offer, A. (2006). Econ J 117, F441-F459.

18. Cawley J, Moran J \& Simon K (2009) The impact of income on the weight of elderly Americans. Health Econ 19, 979-993.

19. Variyam J \& Blaylock J (1998) Unlocking the mystery between nutrition knowledge and diet quality. Food Rev 21, 21-28.

20. Popkin BM, Zizza C \& Siega-Riz AM (2003) Who is leading the change? US dietary quality comparison between 1965 and 1996. Am J Prev Med 25, 1-8.

21. Du S, Mroz TA, Zhai F et al. (2004) Rapid income growth adversely affects diet quality in China - particularly for the poor! Soc Sci Med 59, 1505-1515.

22. Gustavsson K \& Sidenvall B (2002) Food-related health perceptions and food habits among older women. $J$ Adv Nurs 39, 164-173.

23. Donkin AJM, Johnson AE \& Lilley JM (1998) Gender and living alone as determinants of fruit and vegetable consumption among the elderly living at home in urban Nottingham. Appetite 30, 39-51.

24. Cutler DM \& Llera-Muney A (2010) Understanding differences in health behaviors by education. J Health Econ 29, $1-28$.

25. Piantadosi S, Byar DP \& Green SB (1988) The ecological fallacy. Am J Epidemiol 127, 893-904. 
Appendix

Sensitivity analysis, Finnish results

\begin{tabular}{|c|c|c|c|c|c|c|c|c|c|c|}
\hline & \multicolumn{2}{|c|}{ Baseline model } & \multicolumn{2}{|c|}{ Income model } & \multicolumn{2}{|c|}{ Expenditure only model } & \multicolumn{2}{|c|}{ Energy model } & \multicolumn{2}{|c|}{$65+$ model } \\
\hline & $\beta$ & SE & $\beta$ & SE & $\beta$ & SE & $\beta$ & SE & $\beta$ & SE \\
\hline Constant & $123 \cdot 200^{\star \star *}$ & $6 \cdot 875$ & $50 \cdot 220^{\star \star \star}$ & 6.996 & $75 \cdot 310^{\star \star \star}$ & $6 \cdot 193$ & $130 \cdot 900^{\star \star \star}$ & $6 \cdot 910$ & $112 \cdot 900^{\star \star \star}$ & $6 \cdot 686$ \\
\hline Log (total expenditure/CU) & $-8 \cdot 020^{\star \star *}$ & 0.673 & - & - & $-4 \cdot 046^{\star \star *}$ & 0.637 & $-6 \cdot 230^{\star \star *}$ & 0.743 & $-7 \cdot 010^{\star \star \star}$ & 0.667 \\
\hline Food share of expenditure & $-5 \cdot 290^{* \star *}$ & 3.634 & - & - & - & - & $-40 \cdot 800^{\star * \star}$ & $4 \cdot 197$ & $-46 \cdot 400^{\star \star \star}$ & $3 \cdot 656$ \\
\hline Log (income/CU) & - & - & $-1 \cdot 390^{*}$ & $0 \cdot 714$ & - & - & - & - & - & - \\
\hline Log (total energy per capita) & - & - & - & - & - & - & $-3 \cdot 490^{\star * *}$ & $0 \cdot 396$ & - & - \\
\hline \multicolumn{11}{|l|}{ Household type (ref. Couple) } \\
\hline Male alone & $-2 \cdot 040^{\star *}$ & 0.832 & 0.292 & $0 \cdot 866$ & -0.049 & $0 \cdot 800$ & $-1 \cdot 520^{*}$ & $0 \cdot 827$ & -0.570 & $1 \cdot 184$ \\
\hline Female alone & $-1 \cdot 390^{\star \star}$ & 0.622 & $-0 \cdot 120$ & 0.659 & -0.336 & 0.634 & -0.950 & $0 \cdot 617$ & $-1 \cdot 500^{*}$ & 0.782 \\
\hline \multicolumn{11}{|l|}{ Education (ref. Primary) } \\
\hline Secondary & $0 \cdot 785$ & 0.636 & 0.625 & 0.664 & $0 \cdot 827$ & 0.658 & $0 \cdot 829$ & $0 \cdot 627$ & $0 \cdot 328$ & 0.626 \\
\hline Tertiary & $1 \cdot 785^{\star \star}$ & $0 \cdot 700$ & $1 \cdot 428^{*}$ & 0.747 & $2 \cdot 289^{\star \star \star}$ & $0 \cdot 724$ & $1 \cdot 748^{\star \star}$ & 0.692 & $1 \cdot 609^{\star \star}$ & 0.696 \\
\hline \multicolumn{11}{|l|}{ Social group (ref. Pensioner) } \\
\hline Entrepreneur & 0.773 & $1 \cdot 131$ & $0 \cdot 166$ & $1 \cdot 181$ & $0 \cdot 766$ & $1 \cdot 171$ & 0.998 & $1 \cdot 116$ & -0.230 & $1 \cdot 085$ \\
\hline White collar & $1 \cdot 164$ & 0.918 & $1 \cdot 192$ & 0.969 & $1 \cdot 465$ & 0.950 & 0.972 & 0.905 & $-0 \cdot 700$ & $0 \cdot 781$ \\
\hline Blue collar & $-1 \cdot 110$ & $1 \cdot 034$ & $-1 \cdot 120$ & $1 \cdot 085$ & $-1 \cdot 041$ & $1 \cdot 072$ & $-1 \cdot 010$ & $1 \cdot 017$ & $-3 \cdot 040^{\star \star *}$ & 0.902 \\
\hline Other & -0.380 & $1 \cdot 390$ & 0.621 & $1 \cdot 456$ & $0 \cdot 184$ & $1 \cdot 448$ & -0.050 & $1 \cdot 377$ & $-2 \cdot 020$ & $1 \cdot 307$ \\
\hline \multicolumn{11}{|l|}{ Age (ref. $50-54$ or $65-69$ years) } \\
\hline $55-60$ years & 0.500 & 0.912 & $0 \cdot 314$ & 0.952 & $0 \cdot 110$ & 0.948 & $0 \cdot 862$ & 0.900 & - & - \\
\hline $60-65$ years & $1 \cdot 064$ & 0.968 & 0.942 & $1 \cdot 009$ & 0.656 & $1 \cdot 003$ & $1 \cdot 607^{*}$ & 0.956 & - & - \\
\hline $65-70$ years & $1 \cdot 499$ & $1 \cdot 129$ & $1 \cdot 955^{*}$ & $1 \cdot 174$ & $1 \cdot 354$ & $1 \cdot 169$ & $2 \cdot 027^{*}$ & $1 \cdot 114$ & - & - \\
\hline $70-75$ years & $1 \cdot 711$ & $1 \cdot 191$ & 1.953 & $1 \cdot 236$ & $1 \cdot 243$ & $1 \cdot 233$ & $2 \cdot 398^{\star \star}$ & $1 \cdot 176$ & $1 \cdot 379^{\star}$ & $0 \cdot 793$ \\
\hline $75-80$ years & $3 \cdot 251^{\star *}$ & $1 \cdot 271$ & $3.943^{\star \star *}$ & $1 \cdot 315$ & $2 \cdot 934^{\star *}$ & $1 \cdot 315$ & $3 \cdot 745^{\star \star *}$ & $1 \cdot 254$ & $3 \cdot 086^{\star \star *}$ & 0.923 \\
\hline$>80$ years & $1 \cdot 827$ & $1 \cdot 307$ & $3 \cdot 766^{\star \star \star}$ & $1 \cdot 349$ & $2 \cdot 646^{\star}$ & $1 \cdot 351$ & $2 \cdot 802^{\star \star}$ & $1 \cdot 297$ & $2 \cdot 290^{\star \star}$ & 1.008 \\
\hline Year (ref. 2007) & 0.422 & 0.518 & $0 \cdot 188$ & 0.568 & 0.580 & 0.536 & $-0 \cdot 190$ & 0.516 & 0.097 & 0.512 \\
\hline \multicolumn{11}{|l|}{ Quarter (ref. Quarter 4) } \\
\hline Quarter 1 & $1 \cdot 401^{\star \star}$ & 0.686 & $1 \cdot 658^{\star *}$ & 0.714 & $1 \cdot 559^{\star *}$ & $0 \cdot 710$ & $1 \cdot 628^{\star \star}$ & 0.678 & $1 \cdot 607^{\star *}$ & 0.683 \\
\hline Quarter 2 & $1 \cdot 262^{*}$ & 0.659 & 0.906 & 0.687 & 0.999 & 0.681 & $1 \cdot 512^{\star \star}$ & 0.651 & $1 \cdot 442^{\star \star}$ & 0.655 \\
\hline Quarter 3 & $1 \cdot 740^{\star \star}$ & 0.678 & $1 \cdot 781^{\star \star}$ & $0 \cdot 706$ & $1 \cdot 725^{\star \star}$ & $0 \cdot 701$ & $2 \cdot 274^{\star \star \star}$ & 0.671 & $2 \cdot 380^{\star \star \star}$ & 0.674 \\
\hline \multicolumn{11}{|l|}{ Region (ref. South) } \\
\hline West & 0.065 & 0.608 & 0.096 & 0.633 & $-0 \cdot 181$ & 0.642 & $0 \cdot 130$ & $0 \cdot 601$ & $0 \cdot 080$ & 0.605 \\
\hline East & $1 \cdot 225^{\star}$ & 0.720 & $1 \cdot 548^{\star \star}$ & 0.748 & $1 \cdot 066$ & 0.744 & $1 \cdot 232^{*}$ & $0 \cdot 710$ & $1 \cdot 251^{*}$ & 0.715 \\
\hline North & $1 \cdot 916^{\star *}$ & 0.832 & $1 \cdot 869^{\star *}$ & 0.867 & $1.599^{*}$ & 0.861 & $1 \cdot 833^{\star *}$ & 0.820 & $1.933^{\star *}$ & 0.822 \\
\hline Aland & $1 \cdot 400$ & $1 \cdot 480$ & $1 \cdot 346$ & $1 \cdot 542$ & $1 \cdot 532$ & 1.532 & $1 \cdot 458$ & $1 \cdot 478$ & $1 \cdot 818$ & $1 \cdot 482$ \\
\hline$R^{2}$ & \multicolumn{2}{|c|}{$9.5 \%$} & \multicolumn{2}{|c|}{$1.9 \%$} & \multicolumn{2}{|c|}{$3.1 \%$} & \multicolumn{2}{|c|}{$13.3 \%$} & \multicolumn{2}{|c|}{$9.1 \%$} \\
\hline
\end{tabular}

$\mathrm{CU}$, consumption unit; ref., reference category.

${ }^{\star * \star}$ Statistically significant at $1 \%$ level; ${ }^{*}$ statistically significant at $5 \%$ level; * statistically significant at $10 \%$ level. 